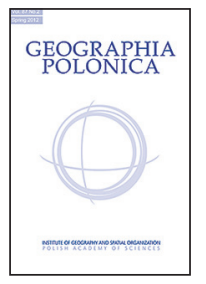

\title{
FROM COMMUNISM TO A FREE-MARKET ECONOMY: A REFLECTION OF SOCIO-ECONOMIC CHANGES IN LAND USE STRUCTURE IN THE VICINITY OF THE CITY (BESKID SĄDECKI, WESTERN POLISH CARPATHIANS)
}

\author{
Anna Bucała-Hrabia \\ Institute of Geography and Spatial Organization \\ Polish Academy of Sciences \\ Św. Jana 22, 31-018, Kraków: Poland \\ e-mail: abucala@zg.pan.krakow.pl
}

\begin{abstract}
Agricultural land is declining in many mountainous regions of the world, often because political and economic changes make agriculture less profitable. This study compared the structure of land use in the Homerka catchment, an area of $19.3 \mathrm{~km}^{2}$ located in the West Polish Carpathians, using GIS techniques and cartographic materials between 1977 and 2009. This period covers the transformation of the Polish economy from a communist system to a free-market economy after 1989. The analysis indicates an increase in the forest area of the Homerka catchment by $18.14 \%$ and a decrease of cultivated land by $82.64 \%$. The grasslands did not change significantly in their area, however, their spatial pattern was very dynamic related to their reduction due to forest expansion and enlargement due to cultivated land abandonment. The area of buildings revealed a continuous increase from $0.21 \%$ to $0.38 \%$. The population density increased from 62 people $/ \mathrm{km}^{2}$ in 1978 to 79 people $/ \mathrm{km}^{2}$ in 2009 , while the population dependent on agriculture decreased from $35 \%$ to below $20 \%$ in the same period. The trend remains one of forest transition where, after a period of deforestation, large areas of land marginally suitable for agriculture are abandoned and left to forest regeneration. However, the driving of the labour force from agriculture to other economic sectors is not accompanied by migration from rural to urban areas.
\end{abstract}

\section{Key words}

land use $\bullet$ agriculture $\bullet$ economic transformation $\bullet$ GIS $\bullet$ mountains 


\section{Introduction}

The land use and land cover (LULC) system of mountains with their fragile environment is very sensitive to socio-economic changes (Macdonald et al. 2000; Bičík et al. 2001; Rudel et al. 2005). This impact can vary in space and time as a result of many factors, both local and regional, acting in various combinations in different geographical locations (Lambin \& Geist 2008).

The contemporary LULC in the Polish Carpathians $\left(19,600 \mathrm{~km}^{2}\right)$ with a forest cover of more than $40 \%$ and population of 2.5 million, of which $65 \%$ live in rural areas, is a consequence of centuries of political and socioeconomic human activity that overlapped on environmental conditions (Długosz \& Soja 1995; Kozak 2009; Łajczak et al. 2014). After World War II, along with the introduction of a communist system in Poland, the Polish Carpathians experienced two types of spatially differentiated LULC changes. The first process, typical for the eastern part of the Polish Carpathians (Bieszczady Mountains and Beskid Niski Mountains), was the displacement of the Ukrainian inhabitants in 1947 that led to a sudden population decrease of 54\% from 1931 to 1950 (Soja 2008) and a collapse in agricultural activity (Wolski 1998; Affek 2016). The second process covered the western and central part of the Polish Carpathians (the Beskidy Mountains, including the Beskid Sadecki Mountains) and involved a gradual withdrawal of agriculture (Kozak 2003; Bucała 2014; Bucała et al. 2016).

Prior to 1989 , development of the public sector in agriculture at the expense of individual farms was a priority for the Polish communist government. The introduction of compulsory deliveries of given amounts of basic crops, which took place after World War II, was an additional form of taxes imposed on farmers. Agriculture was heavily subsidised and production was mainly targeted at socialist markets. The changes in national politics that were more beneficial for individual farmers were introduced in the 1970s and resulted from a constantly deteriorating situation associated with national food supply (Machałek 2013). In 1972, compulsory deliveries were lifted. Farmers were also given the right to pension benefits. These legislative changes gradually reduced farmers' pressure to cultivate the highest and less accessible mountain areas.

The pressure of socio-economic changes associated with the transition from the communist system to a free-market economy accelerated LULC transformation (Bański 2011). In the early phase of transition just after 1989, there was a rapid decline in the profitability of agricultural production as a result of depriving the farmers of special budgetary subsidies for farms in the mountains and the promulgating of a 1988 statute on individual economic entities, which supported the development of activities other than agriculture (Górz 2002, 2003a). In particular, the traditional agriculture in mountains such as the Polish Carpathians became less profitable and this affected LULC changes (Kozak 2005, 2009).

The mid- and low-regions of the Beskidy Mountains and the Bieszczady Mountains, which covers $43 \%$ of the Polish Carpathians, are the largest geomorphic unit inhabited by almost 1 million people (Soja 2002). This is a typical agricultural region with low number of scattered urban areas. Several studies indicate forest expansion and a decrease of cultivated land in the different parts of the Beskidy Mountains over past few decades (Kozak 2003; Ostafin 2009; Bucała 2015). These changes follow a general trend in the whole Polish Carpathians (Kozak 2009) during the socio-economic transition following the collapse of the communist system. However, none of these studies analyse the impact of local socio-economic factors on the LULC changes.

The aim of this study is to present the impact of socio-economic transformation from the late phase of communism to the free-market economy (1977-2009) on LULC changes in the Homerka catchment of the Western Polish Carpathians. It was hypothesised that the location of the catchment in proximity to urban center additionally influences sources 
of income of the local population, which are also reflected in the LULC changes.

\section{Study area}

The study was carried out in the Homerka catchment $\left(19.3 \mathrm{~km}^{2}\right)$ which dissects the northeastern part of the Beskid Sadecki Mountains in the Western Polish Carpathians (Fig. 1). The Homerka stream (9.3 km length) originates from the springs on the slopes of the main ridge reaching $1050 \mathrm{~m}$ a.s.l. The stream joins the Kamienica Nawojowska river at 370 m a.s.l. In the Homerka catchment, medium-high ridges and deep $V$-shaped valleys are the main relief forms. The catchment encompasses two geomorphological units: (a) a foothills unit covering the lower part of the catchment, with ridges up to $600 \mathrm{~m}$ a.s.l., built of marls, calcareous sandstones, variegated shells with a minor contribution of Magura sandstones, (b) the Beskidian unit including the middle and upper part of the catchment, with ridges up to 1050 m a.s.l., built of Magura sandstones (Niedziałkowska 1981).
Most of the catchment slopes are steeper than $15^{\circ}(71 \%$ of the area) (Fig. 2) and they are convex or convex-concave in shape.

The Homerka catchment geomorphic units correlate with two vertically-differentiated climatic zones: a) a temperate warm zone with a mean annual temperature of $8-6^{\circ} \mathrm{C}$ extending up to $650-700 \mathrm{~m}$ a.s.l. and b) extending above a temperate cold zone $\left(4-6^{\circ} \mathrm{C}\right)$, (Hess 1965). Mean annual precipitation reaches $955 \mathrm{~mm}$ (1971-2011) at the Research Station in Frycowa IGSO PAS located at $415 \mathrm{~m}$ a.s.I. In the catchment brown soils dominate, only in the narrow valley bottom have alluvial soils have formed. Soil thickness does not show close correlation with elevation (Adamczyk \& Słupik 1981). The foothill zone is occupied mainly by deciduous forests (Tilio-Carpinetum), such as hornbeams (Carpinus betulus) and rarely pedunculate oak Quercus robur. The lower mountain zone (600-1050 m a.s.l.) is represented by mixed forests, such as beech (Fagus sylvatica L.) and fir (Abies alba Mill.) (Staszkiewicz 1981; Grodzińska \& Szarek-Łukaszewska 1997).

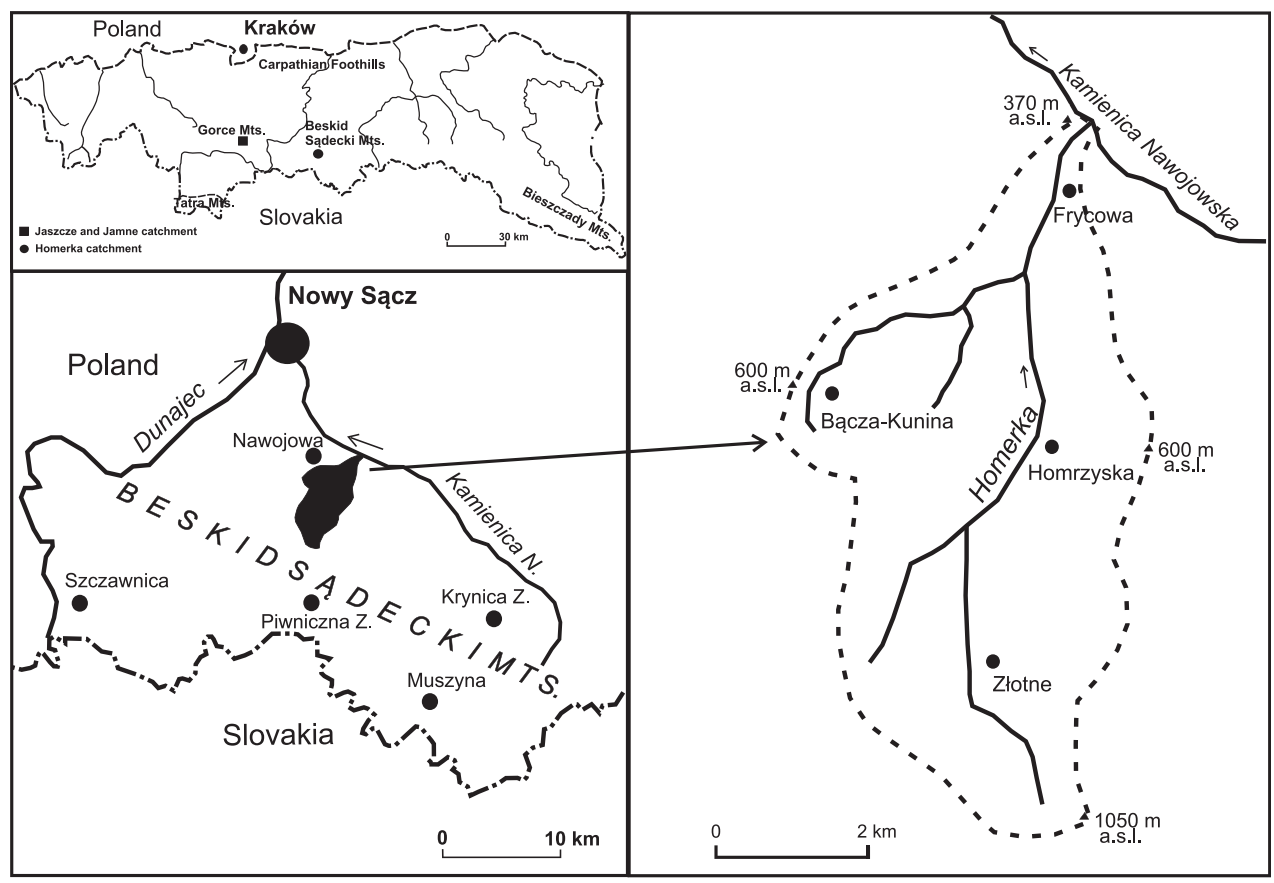

Figure 1. Study area 

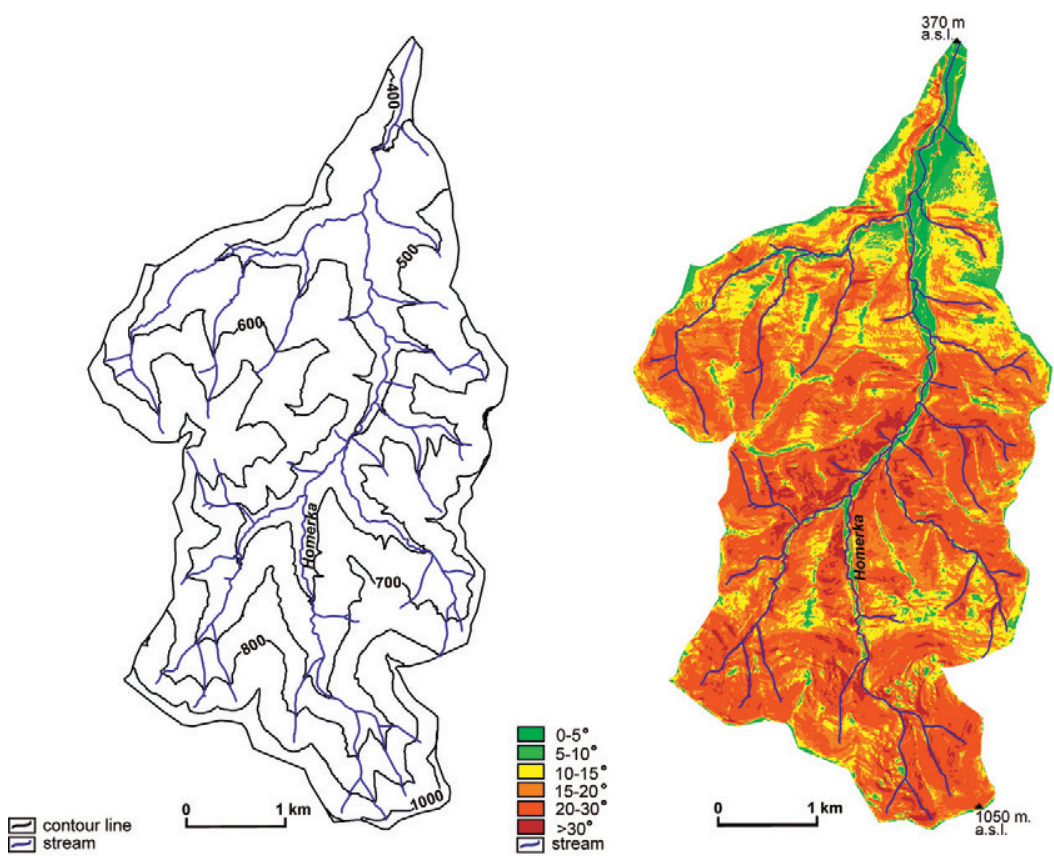

Figure 2. Elevations and slope inclinations in the Homerka catchment

From an administrative point of view, the Homerka catchment is located in the Nawojowa commune $\left(51.13 \mathrm{~km}^{2}\right)$. The catchment is inhabited by 1526 people living in four villages Frycowa, Homrzyska, Bącza-Kunina and Złotne (Central Statistical Office 1978-2011), which contributes 19\% of the Nawojowa commune population. At a distance of $10 \mathrm{~km}$ from the catchment, Nowy Sacz city is located with a population of 84,556 in 2009 (Central Statistical Office 1978-2011). This is the main industrial, service and cultural centre of the Beskid Sadecki region. Several small spa towns such as Muszyna (4965 inhabitants in 2009), Piwniczna-Zdrój (5 836 inhabitants in 2009) and Krynica-Zdrój (10,879 inhabitants in 2009) are located $10-20 \mathrm{~km}$ around the Homerka catchment.

\section{Materials and methods}

The changes in LULC were derived from panchromatic aerial photos at a scale of $1: 16,000$ for the year 1977, 1:25,000 for 1987, 1:26,000 for 1996 and orthophotomaps at a scale of 1:5,000 for 2009. Geometric corrections were performed to rectify all the maps and images using the Transverse Mercator projection system in a GIS ILWIS 3.3 environment (International Institute for Aerospace Survey and Earth Sciences 1997). In order to standardise the values of the maps from four different time periods, six consistent LULC categories were defined: forests, grasslands (meadows and pastures), cultivated lands, groups of trees and shrubs, tree belts along roads and buildings. The analysis was supported by the author's field surveys of the Homerka catchment in 2014.

A Digital Elevation Model (DEM) (pixel size $1 \mathrm{~m}$ ) was available at the Centre of Geodetic and Cartographic Documentation (CODGiK). The DEM served to generate derivative maps of a proportion of the LULC in relation to slope inclination, as well as its changes in the $100 \mathrm{~m}$ classes of elevation across various time scales. The area of the Homerka catchment and length of the Homerka stream were delineated and 
calculated with the help of a topographic map (1:10,000) from 2001 and an orthophotomap from 2009, respectively.

The population development and sources of maintenance in the Homerka catchment, Nawojowa commune and Nowy Sacz were presented on the basis of statistical records from Central Statistical Office for 1978-2011.

\section{Results}

\section{LULC changes in the communist system (1977-1987)}

In 1977 over half of the Homerka catchment was occupied by forest (57.56 \%). It formed a continuous complex in the middle and upper part of the catchment with steep and north-facing slopes (Fig. 3). Above an elevation of $800 \mathrm{~m}$ a.s.l., forest contribution exceeded $90 \%$. Farmlands (grassland and cultivated land) dominated at the bottom of the Homerka valley and foothills. In this part, below $600 \mathrm{~m}$ a.s.l., cultivated land covered on average $24 \%$ of each 100 m altitude class. The largest contribution of the cultivated land (36.05\%) was at elevations of $400-500 \mathrm{~m}$ a.s.l. and on slopes inclined below $15^{\circ}$. The upper boundary of cultivated land reached 850 m a.s.I. In 1977-1987, cultivated land was also observed on landslides that cover 6\% of the Homerka catchment (SOPO 2006-2025, http://geoportal.pgi.gov.pl). Most of the landslides were located in the forest, about $4 \%$ and only $2 \%$ of landslides occurred within cultivated land and grasslands. Groups of trees and bushes, as well as belts of trees and shrubs were concentrated along the roads (1.73\%). Houses and farm storage buildings, located mainly in the lower part of the catchment occupied only $0.21 \%$.

Up to 1987, just before the communist system collapsed, the forest area increased by $6.72 \%$ to $61.43 \%$, mainly in the lower and middle part of the Homerka catchment. Cultivated land decreased by $29.03 \%$ to $10.22 \%$. The upper boundary of cultivated land decreased by $100 \mathrm{~m}$ in the Homerka catchment. The largest decrease in cultivated land

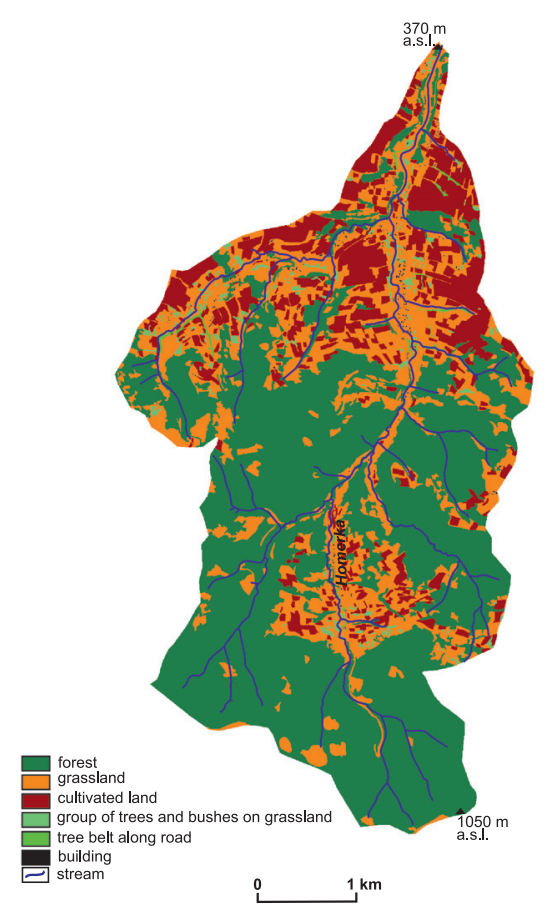

Figure 3. LULC in the Homerka catchment in the year 1977

occurred on slopes steeper than $15^{\circ}$. However, cultivated land still occupied on average 16\% of each $100 \mathrm{~m}$ altitude class up to $600 \mathrm{~m}$ a.s.l. Grassland did not change its area significantly. In this period the area of buildings increased by $14.3 \%$ (Tab. 1.)

\section{LULC changes during the transformation to a free-market economy (1987-2009)}

In the period 1987-1996, which covers the early stage of transformation from the communist system to a free-market economy, the forests slowly increased by $5.33 \%$, while cultivated land rapidly decreased by $49.21 \%$. The largest increase of forest area occurred on slopes of an inclination of up to $5^{\circ}$, ca. $15 \%$ in the lower part of catchment. The area of buildings again noticed a significant increase by $45.83 \%$. Other land use types did not change their area significantly (Tab. 1, Fig. 4). 
Table 1. LULC changes and its annual dynamic (\%) in the Homerka catchment for the period 1977-2009

\begin{tabular}{|l|r|r|r|r|r|r|r|}
\hline \multicolumn{1}{|c|}{ LULC } & 1977 & 1987 & 1996 & 2009 & $\begin{array}{r}1977- \\
1987\end{array}$ & $\begin{array}{r}1987- \\
1996\end{array}$ & $\begin{array}{r}1996- \\
2009\end{array}$ \\
\hline Forest & 57.56 & 61.43 & 64.71 & 68.00 & 0.39 & 0.36 & 0.25 \\
Grassland & 26.10 & 26.92 & 28.31 & 27.54 & 0.08 & 0.15 & -0.06 \\
Cultivated land & 14.40 & 10.22 & 5.19 & 2.50 & -0.42 & -0.56 & -0.21 \\
Group of trees and bushes & 1.29 & 0.97 & 0.92 & 0.97 & -0.03 & -0.01 & $<0.01$ \\
Tree belt along road & 0.44 & 0.22 & 0.52 & 0.61 & -0.02 & 0.03 & 0.01 \\
Buildings & 0.21 & 0.24 & 0.35 & 0.38 & $<0.01$ & 0.01 & $<0.01$ \\
\hline
\end{tabular}

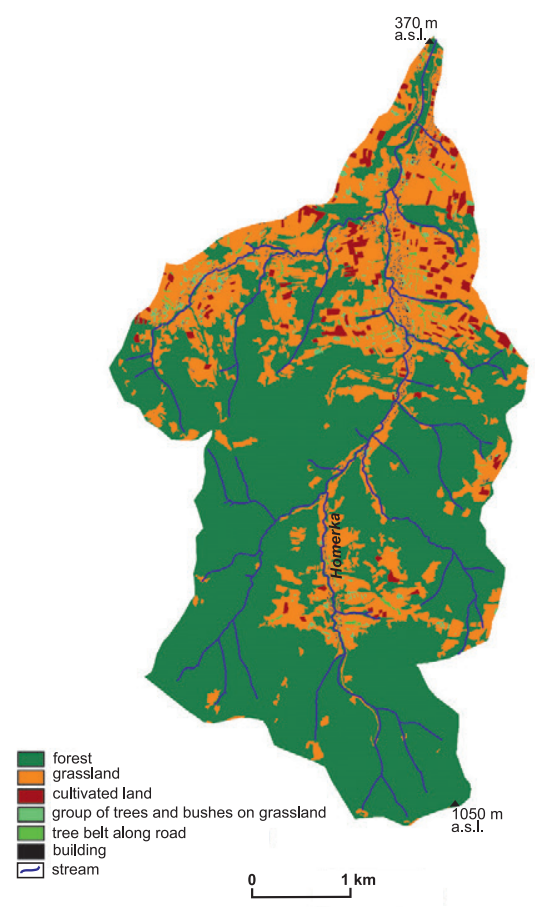

Figure 4. LULC in the Homerka catchment in the year 2009

During 1996-2009, which includes the accession of Poland to the European Union in 2004, the general tendencies in LULC change remained the same. Further expansion of forest by $5.08 \%$ was observed. Forest succession occurred mainly in the lower part of the catchment within abandoned meadows and along streams, as well as within intraforest glades on ridges. Forest dominates at all elevations except 300-500 m a.s.l. where the contribution of farmland is highest. Cultivated land was again reduced by $51.83 \%$ to only $2.50 \%$ of the catchment with a tendency to abandonment on the steepest slopes. The upper boundary of cultivated land did not change compared to 1987 . Up to 750 m a.s.l., the cultivated land contribution did not exceed on average $1.10 \%$ of each $100 \mathrm{~m}$ altitude class in the Homerka catchment. The largest area of cultivated land remained close to houses below $600 \mathrm{~m}$ a.s.l. where it covered $4.50 \%$. The cultivated landslides visible in the previous analysed period were occupied by grasslands with visible encroachment of bushes and trees. These small vegetation patches have a tendency to conversion to forest. The grasslands decreased a little, by $2.83 \%$ and they occupied a similar area to 1977 (Fig. 5, 6).

\section{Major LULC conversions 1977-2009}

The study of LULC during the 1977-2009 period revealed that stable land use (the same land use category in each time period) dominates in the Homerka catchment, covering $71.32 \%$ of its total area. In each of the three analysed periods, there is a gradual increase in the percentage of stable areas in the Homerka catchment (Tab. 2, Fig. 7). The stable land use area mainly consists of large blocks of forest at the highest elevations and less accessible steep slopes, core areas of large grasslands and settlements located at the lower part of the catchment. Farmland was the least stable category of land use. In the period 1977-2009, 55.27\% of forest was not subject to any change in the 


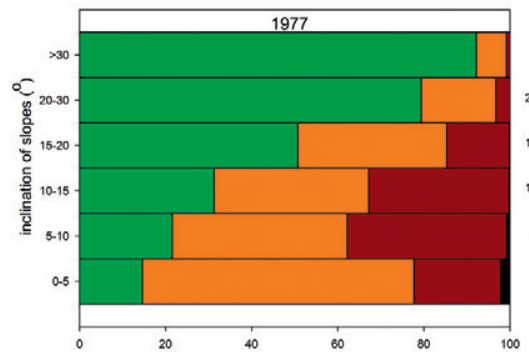

(\%)

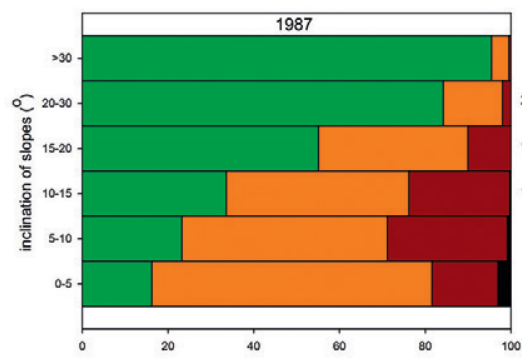

(\%)

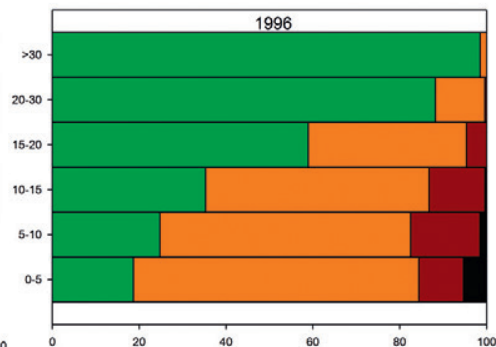

(\%)

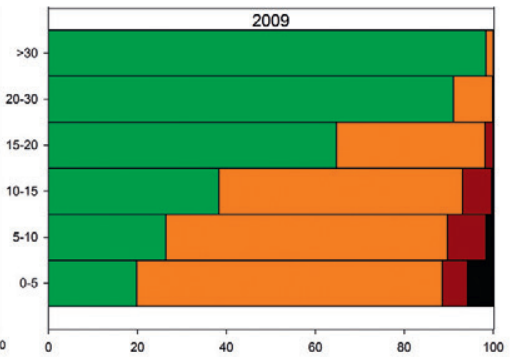

(\%)

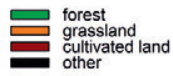

Figure 5. LULC changes in slope inclinations in the Homerka catchment for the period 1977-2009

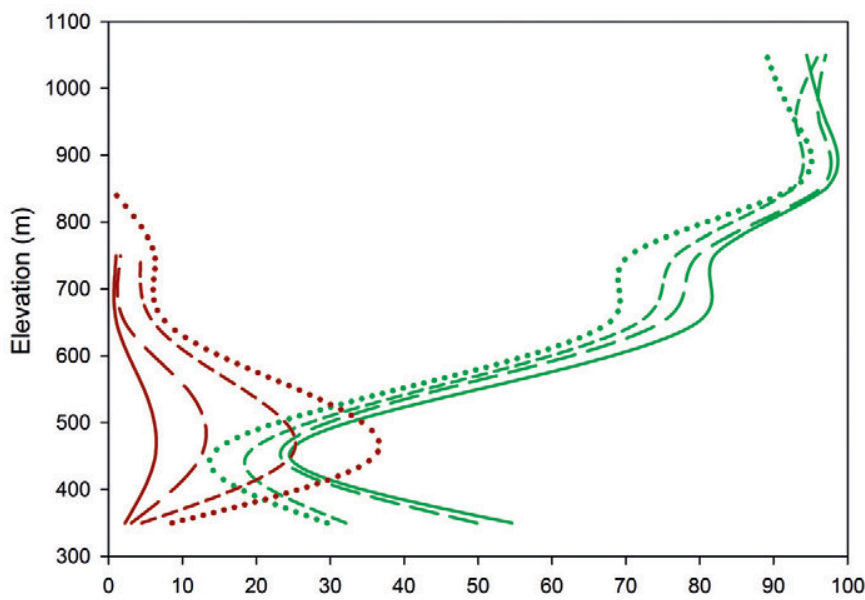

(\%)

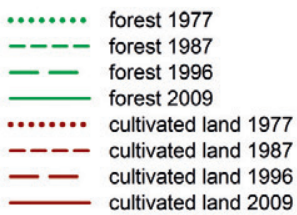

Figure 6. Changes in the proportion of forest cover and cultivated land land with elevation of each $100 \mathrm{~m}$ altitude class in the Homerka catchment for the period 1977-2009 


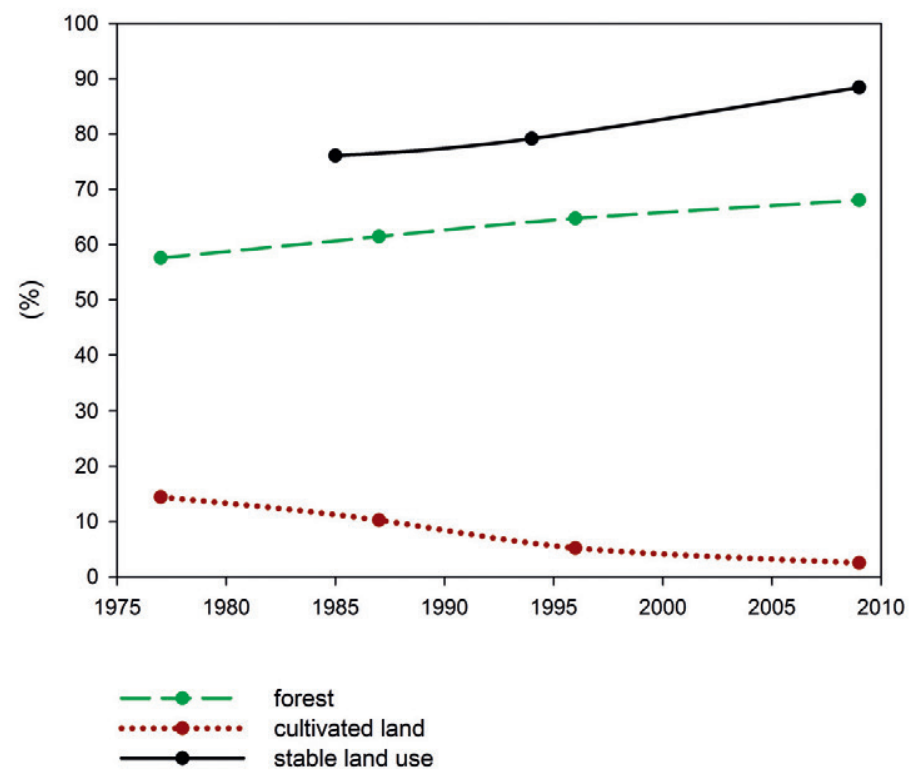

Figure 7. LULC changes in the Homerka catchment for the period 1977-2009

Table 2. Predominant types of LULC changes (claiming over $0.5 \%$ of the total area of the Homerka catchments)

\begin{tabular}{|l|c|c|c|c|}
\hline \multirow{2}{*}{ Land use categories } & \multicolumn{4}{|c|}{ Homerka catchment } \\
\cline { 2 - 5 } & $1977-1987$ & $1987-1996$ & $1996-2009$ & $1977-2009$ \\
\hline without changes & 76.06 & 79.14 & 88.39 & 71.32 \\
forest to grassland & 3.21 & 2.87 & - & 2.14 \\
forest to cultivated land & 0.48 & - & - & - \\
grassland to forest & 6.08 & 5.44 & 3.46 & 10.05 \\
grassland to cultivated land & 3.24 & 2.37 & 1.48 & 0.63 \\
cultivated land to forest & 0.93 & 0.55 & - & 1.87 \\
cultivated to grassland & 6.93 & 6.87 & 4.07 & 10.30 \\
\hline
\end{tabular}

Homerka catchment. In contrast, only $1.81 \%$ of cultivated land from 1977 is still cultivated. The remaining cultivated land was converted to grasslands and forests. About 10.05\% of grassland area became overgrown with forests due to natural succession. A small percentage of grassland area was also intended for buildings.

\section{Socio-economic development} of the study area (1978-2009)

In 1978-2009, both in the Homerka catchment and in the Nawojowa commune, the population revealed an increasing trend from 1,193 and 5,834 in 1978 to 1,526 and 8,074 in 2009 respectively. Only about $35 \%$ of the Homerka catchment inhabitants was dependent 
on agriculture in 1978, while in 1970 it was almost $60 \%$. This downward trend continued to below $20 \%$ in 2009. A similar tendency was observed in the Nawojowa commune where the population dependent on agriculture decreased by 69\% between 1978 and 2011 (Central Statistical Office 1978-2011) (Fig. 8A).
The proximity of Nowy Sacz city has an important impact on the high population employment outside the agricultural sector. This local urban centre has noted a rapid population growth and development of workplaces during the late communism period. In this period, the population of Nowy Sacz grew by 23\%
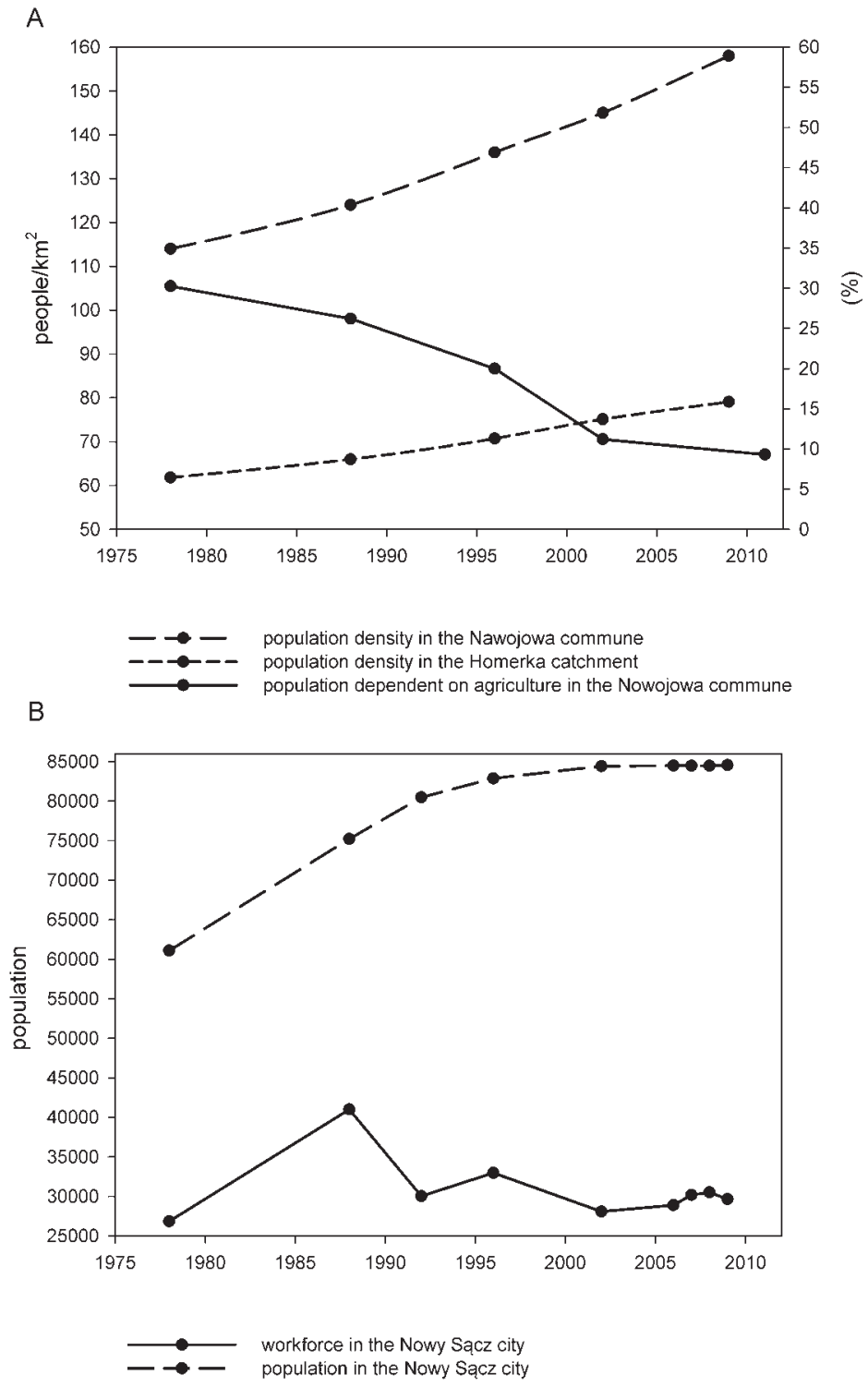

Figure 8. A. Population density and population dependent on agriculture, in the Homerka catchment and in the Nawojowa commune B. Workforce and population in Nowy Sącz (Central Statistical Office, 1978-2011) 
from 61,100 in 1978 to 75,217 in 1988. In 1988, this city employed 41,000 people including inhabitants of villages in the Homerka catchment. In 1988, 22,370 people (Górz \& Uliszak 2005) was arriving every day to work in Nowy Sacz (Central Statistical Office 1978-2011). Nowy Sacz also played an important administrative role as the capital of the voivodeship until 1997 (Fig. 8B).

At the turn of communism collapse and the onset of the free-market economy the population of the city grew at much slower rates to 82,877 in 1996 and only 84,556 in 2009. In particular, the early period of the free-market economy characterised the collapse of several large industrial enterprises in Nowy Sacz, which caused a rapid decrease in employment to 30,030 in 1992 (Central Statistical Office 1978-2011).

In 2011, only 10,668 people commuted every day to work in Nowy Sacz. Little more than $25 \%$ of the population employed outside the agricultural sector in Nawojowa commune had a job in Nowy Sacz (Badanie funkcji ... 2010; Central Statistical Office 1978-2011).

On the other hand, the collapse of communism has given a new impulse to private sector developments such as building construction, transport and tourism. In 2009, 326 small construction enterprises were registered in the Nawojowa commune and $15 \%$ of these enterprises are located in the villages of the Homerka catchment.

\section{Discussion}

Analysis of cartographic materials and a conducted field survey, supported by socio-economic statistical data allowed the detection of trends and dynamics in LULC changes occurring in the Homerka catchment located in the Beskid Sadecki region of the Western Polish Carpathians. The forest area in the Homerka catchment increased by $18.14 \%$ during the whole period analysed (1977-2009). An increase in forest area up to $97 \%$ above $900 \mathrm{~m}$ a.s.l. shows a similarity with processes in the other parts of the Beskidy Mountains located in the Western Polish Carpathians.
In the upper parts of these mountains, above $900 \mathrm{~m}$ a.s.l. the forest area usually exceeds 90\% (Troll 1999; Kozak 2005; Bucała 2015). The area of cultivated land decreased by $82.64 \%$, with a lowering of its upper boundary from $850 \mathrm{~m}$ a.s.l. to $750 \mathrm{~m}$ a.s.l. The grasslands did not change their area significantly in the Homerka catchment. However, their spatial pattern was very dynamic related to its reduction along with forest expansion and enlargement due to the abandonment of cultivated land. The area of buildings revealed a continuous increase from $0.21 \%$ to $0.38 \%$. The population density increased from 62 people $/ \mathrm{km}^{2}$ in 1978 to 79 people/ $\mathrm{km}^{2}$ in 2009, while the population dependent on agriculture decreased from 35\% to below $20 \%$ in the same period (Central Statistical Office 1978-2011).

The largest dynamic of LULC changes OCcurred just before the collapse of communism and during the early stages of the free-market economy. The highest dynamic of forest cover increase of about $0.39 \%$ and $0.36 \%$ annually was observed in the years 1977-1987 and 1987-1996, respectively (see Tab. 1). In the same years, the highest rates of cultivated land abandonment (of about $0.42 \%$ and $0.56 \%$ respectively per year) were also noted. This general trend of LULC transformation correlates with changes of income sources of the Homerka catchment and Nawojowa commune inhabitants.

In 1978 only $35.1 \%$ of the Homerka catchment population was dependent on agriculture. This contribution decreased a little to $34.0 \%$ in 1988 . A similar trend is observed for the Nawojowa commune. This decrease of agriculture in income of the population is probably related to the dynamic growth of workplaces in the neighbouring Nowy Sacz until 1988 (Central Statistical Office 1978-2009). Many labourers in Nowy Sacz constituted people from villages located around the city including the Nawojowa commune (Górz \& Uliszak 2005). With the increase in employment in off-farm activities, the first group of farmer-pensioners was also developed, which accounted in 1988 
for $19.1 \%$ of the residents of the Nawojowa commune.

The transformation to a free-market economy after 1989 caused slower population growth and a rapid reduction in workplaces in Nowy Sacz (Central Statistical Office 19782011). At the same time, new demographic trends were observed such as migration from the city to suburban areas, as well as people returning from the industrial Upper Silesia region due to the collapse of large industrial plants (Uliszak 2013). It also coincides with traditional natural population growth in the Beskid Sadecki region, one of the highest in Poland (Górz \& Uliszak 2005). Thus, a continuous increase in building area was noted in the Homerka catchment.

The reduction of workplaces in Nowy Sacz did not cause a return to agricultural activity. Depriving the farmers of special budgetary subsidies for farms in the mountains between 1988 and 2004 (access of Poland to the EU) perpetuated a low economic attraction of land cultivation (Górz 2002, 2003a). The main sources of income for the Homerka catchment inhabitants were still off-farm activities in the next decades. Due to the high economic activity, they undertook parttime or permanent jobs in EU countries such as Austria, Germany and Italy (Górz 2003 b). With the increase in employment in off-farm activities, the group of farmerpensioners increased to $44.4 \%$ of the residents of Nawojowa commune in 2002. With a constant, usually small income, the people are not interested or, because of old age, are not able to cultivate the lands in an unfavourable mountain environment. Moreover, despite high economic activity of the population, unemployment constitutes about $10 \%$ of both the Homerka catchment and Nawojowa commune population in the 2000s (Central Statistical Office 1978-2011).

The impact of Nowy Sacz on sources of inhabitant's income and LULC can be assessed through a comparison of changes in the population dependent on agriculture and LULC structure of the Homerka catchment in the Nawojowa commune, with the Jaszcze and
Jamne catchments $\left(20.30 \mathrm{~km}^{2}\right)$ in the Ochotnica commune located in the Gorce Mountains (also in the Western Polish Carpathians), but far from urban centres (see Fig. 1; Bucała 2015). Nowy Sacz located in the proximity of the Nawojowa commune, had a lower contribution of population dependent on agriculture and lower rates of decrease compared to the Ochotnica commune in the whole period analysed (1977-2009) (Fig. 9).

However, the role of Nowy Sacz in LULC changes is more complex. Both the Homerka and the Jaszcze and Jamne catchments reveal similar trends of forest change, its contribution and location in their middle and upper parts. This suggests that under predominant environmental and socio-economic conditions the largest possible areas of both catchments were converted to farmland. The deforestation was inherited from the past and maintained by pressure from the communistic government to increase agricultural production. A persistent shortage of agricultural products on the market at that time, caused inhabitants of the Homerka catchment to cultivate land to meet their own food needs. This process was independent of their additional off-farm jobs in Nowy Sacz. Agricultural activity was also facilitated by better environmental, especially climate conditions for crop cultivation in the Homerka catchment, which is located $250 \mathrm{~m}$ lower than the Jaszcze and Jamne catchments. In effect, the contribution of cultivated land was larger in the Homerka catchment compared to the Jaszcze and Jamne catchments during the communist period.

The general trend of LULC changes in the Homerka catchment in the Beskid Sadecki Mountains of the Western Polish Carpathians is similar to those occurring after 1989 in neighbouring countries, which also belonged to the East European communist regimes. After the communist economy, most East European countries carried out land reforms to restructure the farming sector, individualise land use and privatise farmland (Kuemmerle et al. 2009). In effect, cultivated land has been mostly replaced by pastures, while pastures were 

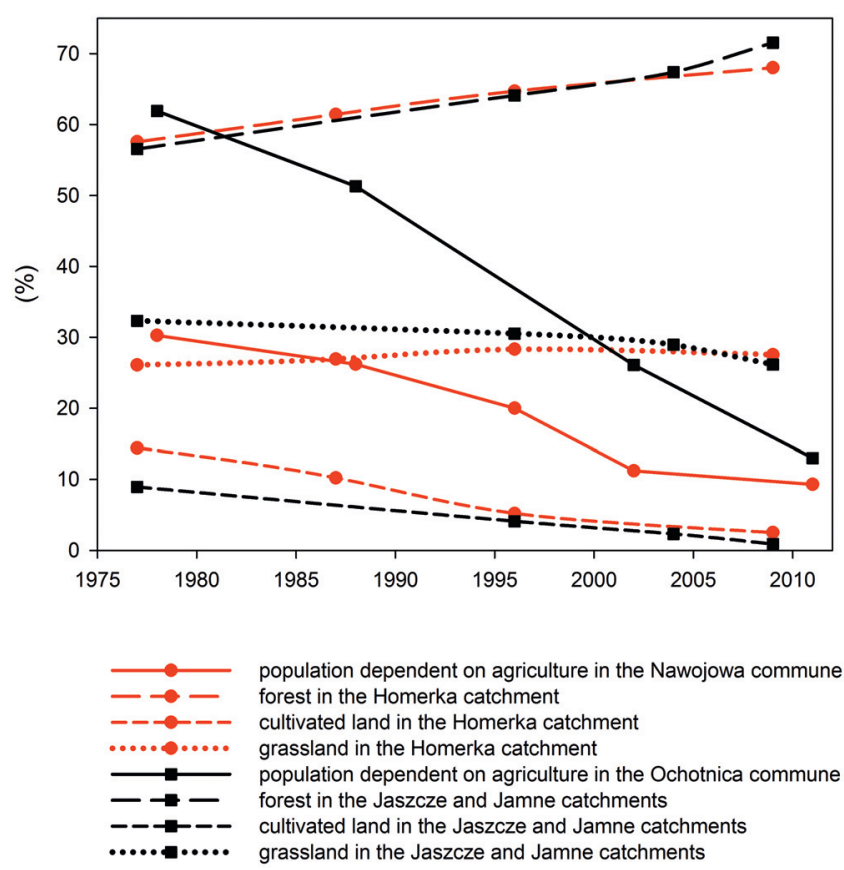

Figure 9. LULC changes in the Homerka and the Jaszcze and Jamne catchments on the background of population dependent on agriculture in the Nawojowa and the Ochotnica communes (Central Statistical Office, 1978-2011)

further overgrown by forest in Czechia (Bičík et al. 2001, 2012,), Slovakia (Olah et al. 2009; Šebo \& Nováček 2014) and East Germany (Baessler \& Klotz 2006). For example, in the Hoštka, a rural area (Czechia) which is situated near the German border (mean altitude $570 \mathrm{~m}$ a.s.l.) in 1990, arable land occupied $59 \%$ of the total area. This high proportion has decreased to $2 \%$ in 2010. Arable land has been mostly replaced by pastures whose area increased from 5\% to 57\% (Kupková \& Bičík 2016). An exception is the less economically developed region of the Romanian Carpathians, where forest cover loss was observed (Munteanu et al. 2014). In Arges County, an area of $6.82 \mathrm{~km}^{2}$ located in south-central Romania, forest cover of about $38 \%$ was stable between 1990 and 2005. In contrast, cropland decreased from $35.1 \%$ to $27.6 \%$, mainly at the expense of grassland whose area increased from 16.4 to $23.2 \%$ in this period (Kuemmerle et al. 2009).
The changes in the LULC structure are similar to those that have continued in the French Alps since the first half of the nineteenth century (Mather \& Needle 1998; Whited 2000; MacDonald et al. 2000; Didier 2001), Swiss Alps (Wohl 2006; Gerllich et al. 2007) and observed since the beginning of the twentieth century in the Spanish Pyrenees (García-Ruiz 2010). In all these mountains, forest expansion resulted from cultivation abandonment due to low income from farming and was accompanied by people migration to more fertile and urbanised lowlands. It must be noted however that rural areas of the Western Polish Carpathians still record a population growth despite a decrease of population dependent on agriculture.

\section{Conclusions}

The political and socio-economic changes related to the transition from the communist 
system to a free-market economy, then to the accession of Poland to the European Union had profound impacts on the profitability of agriculture production in the Western Polish Carpathians.

The general trend, the increase of forest area at the expense of cultivated land as well as decrease of population dependent on agriculture in the Homerka catchment located in Beskid Sadecki Mountains confirm tendencies observed earlier in some parts of the Western Polish Carpathians. However, the main sources of income for the study area inhabitants were off-farm activities (construction, services, agritourism) already from 1970s. Thus, the location of the Homerka catchment and Nawojowa commune in proximity of regional urban centres caused a lower contribution of population dependent on agriculture and its lower rates of decrease compared to peripheral mountain regions in the period 1979-2009. In this case, the urban centre with a decreasing but still relatively large number of workplaces helped overcome the negative impact of communism collapse and the accession of Poland to the European Union.

Analyses of LULC and socio-economic changes in the Homerka catchment reveal

\section{References}

AdamczYk B., SŁupIK J., 1981. Gleby [in:] L. Starkel (ed.), Warunki naturalne zlewni Homerki i jej otoczenia, Dokumentacja Geograficzna, 3, Warszawa: Instytut Geografii i Przestrzennego Zagospodarowania PAN, pp. 51-72.

AfFeK A., 2016. Zależności między pokryciem terenu a własnościq gruntów na tle uwarunkowań przyrodniczych w zlewni górnego Wiaru w ciqgu ostatnich 230 lat. Prace Geograficzne, 251, Warszawa: Instytut Geografii i Przestrzennego Zagospodarowania PAN.

BADANIE FUNKCJI, POTENCJAŁÓW I TRENDÓW ROZWOJOWYCH MIAST W WOJEWÓDZTWIE MAŁOPOLSKIM 2010. Kraków: Instytut Geografii i Gospodarki Przestrzennej UJ, Instytut Spraw Publicznych UJ. that economic development has created enough non-farm jobs to pull farmers off of the land and forest expansion. The trends remain a pathway of forest transition proposed by Rudel et al. (2005) when, after a period of deforestation, large areas of land marginally suitable for agriculture are abandoned and left to forest regeneration. However, one exception must be underlined. The labour force is driven from agriculture to other economic sectors but not from rural to urban areas in the case of the Homerka catchment and the Nawojowa commune.

The changes in LULC structure in past decades are similar to those observed in the mountains of Western Europe since the first half of the nineteenth century. However, the cessation of traditional farming was not accompanied by a decrease in population density in the Beskidy Mountains. The migration of people from rural areas is still lower in comparison to the relatively high rate of natural population increase.

Editors' note:

Unless otherwise stated, the sources of tables and figures are the authors', on the basis of their own research.

Baessler C., Klotz S., 2006. Effects of changes in agricultural land-use on landscape structure and cultivated weed vegetation over the last 50 years. Agriculture, Ecosystems \& Environment, vol. 115, no. 1, pp. 43-50.

BAŃSKI J., 2011. Changes in agricultural land ownership in Poland in the period of the market economy. Agricultural Economics, vol. 57, no. 2, pp. 93-101.

BIČIK I., JeLEČEK L., ŠTĚPÁNEK V., 2001. Land-use changes and their social driving forces in Czechia in the 19th and 20th centuries. Land Use Policy, vol. 18, no. 1, pp. 65-73.

BıČIK I., KuPKOVÁ L., ŠTYCH P., 2012. Changes of land use structure in Czechia: From local patterns to a more complex regional organization [in:] I. Bičík, Y. Himiyama, J. Feranec, P. Štych (eds.) Land Use/Cover Changes in Selected 
Regions in the World, vol. 7, Asahikawa: International Geographical Union Commission on Land Use/Cover Change; Hokkaido University of Education, pp. 5-12.

BuCAŁA A., 2014. The impact of human activities on land use and land cover changes and environmental processes in the Gorce Mountains (Western Polish Carpathians) in the past 50 years. Journal of Environmental Management, vol. 138, pp. 4-14.

BuCAtA A., 2015. Land use/cover changes related to transition from communist system to free market economy in the Gorce Mts., Polish Carpathians, Poland [in:] I. Bičík, Y. Hiyama, J. Feranec, L. Kupková (eds.), Land use/cover changes in selected regions in the world, vol. 7, Asahikawa: International Geographical Union Commission on Land Use/Cover Change; Hokkaido University of Education, pp. 43-48.

Bucata A., Budek A., Kozak M., Starkel L., WieJACZKA Ł., 2016. Kierunki przemian środowiska przyrodniczego dolin gorczańskich. Prace Geograficzne, 252, Warszawa: Instytut Geografii i Przestrzennego Zagospodarowania PAN.

Central Statistical Office of Poland for the years 1978-2011.

DIDIER L., 2001. Invasion patterns of European larch and Swiss stone pine in subalpine pastures in the French Alps. Forest Ecology and Management, vol. 145, no. 1-2, pp. 67-77.

DŁugosz Z., Soja M., 1995. Population [in:] J. Warszyńska (ed.), Karpaty Polskie: Przyroda, człowiek i jego działalność, Kraków: Uniwersytet Jagielloński, pp. 209-217.

García-Ruiz J.M., 2010. The effects of land uses on soil erosion in Spain: A review. Catena, vol. 81, no. 1, pp. 1-11.

Gellrich M., Baur P., Koch B., Zimmermann N., 2007. Agricultural land abandonment and natural forest re-growth in the Swiss mountains: A spatially explicit economic analysis. Agriculture, Ecosystems \& Environment, vol. 118, no. 1, pp. 93-108.

Górz B., 2002. Współczesne przemiany na obszarach wiejskich Podhala. Przeglad Geograficzny, vol. 74, no. 3, pp. 451-468.

Górz B., 2003a. Społeczeństwo i gospodarka Podhala w okresie transformacji. Kraków: Akademia Pedagogiczna.

Górz B. 2003b. Współczesne procesy społeczno-gospodarcze i przyszłość wsi w kotlinach śródkarpackich (na przykładzie wsi Gołkowice Dolne w pow. nowosadeckim) [in:] B. Górz, Cz. Guzik (eds.), Współczesne przekształcenia i przyszłość polskiej wsi, Studia Obszarów Wiejskich, 4, pp. 163-180.

Górz B., Uliszak R., 2005. Procesy ludnościowo-osadnicze na Sadecczyźnie [in:] B. Górz (ed.), Kraków: Akademia Pedagogiczna, pp. 279-298.

Grodzińska K., Szarek-ŁuKaszewska G., 1997. Polish mountain forests: Past, present and future. Environmental Pollution, vol. 98, no. 3, pp. 369-374.

Hess M., 1965. Piętra klimatyczne w polskich Karpatach Zachodnich. Zeszyty Naukowe UJ, Prace Geograficzne, 11.

International Institute for Aerospace Survey and Earth SCIENCES, 1997. ILWIS - The Integrated Land Water Information System. User's Guide, Enschede: The Netherlands.

KOZAK J., 2003. Forest cover change in the Western Carpathians in the past 180 years: A case study in the Orawa region in Poland. Mountain Research and Development, vol. 23, no. 4, pp. 369-375.

KozAK J., 2005. Zmiany powierzchni lasów w Karpatach Polskich na tle innych gór świata. Kraków: Uniwersytet Jagielloński.

KozAK J., 2009. Forest cover changes and their drivers in the Polish Carpathian Mountains since 1800 [in:] H. Nagendra, J. Southworth (eds.), Reforesting Landscapes, Dordrecht: Springer, pp. 253-273.

Kuemmerle T., Müller D., Griffiths P., Rusu M., 2009. Land use change in Southern Romania after the collapse of socialism. Regional Environmental Change, vol. 9, no. 1, pp. 1-12.

KuPKOVÁ L., BıČík I., 2016. Landscape transition after the collapse of communism in Czechia. Journal of Maps, vol. 12, issue sup. 1, pp. 526-531.

LAMBIN E.F., GeIST H.J. (eds.), 2008. Land-use and land-cover change: Local processes and global impacts. Berlin: Springer Science \& Business Media.

Łauczak A., Margielewski W., Raczkowska Z., ŚwIECHOWICZ J., 2014. Contemporary geomorphic processes in the Polish Carpathians under changing human impact. Episodes, vol. 37, no. 1, pp. 21-32.

MacDonald D., Crabtree J.R., Wiesinger G., Dax T., Stamou N., Fleury P., Gutierrez LazplTA J., GiBON A., 2000. Agricultural abandonment 
in mountain areas of Europe: Environmental consequences and policy response. Journal of Environmental Management, vol. 59, no. 1, pp. 47-69.

MaChatek M., 2013. Przemiany polskiej wsi w latach 1918-1989. Klio - Czasopismo Poświęcone Dziejom Polski i Powszechnym, vol. 26, no. 3, pp. 55-80.

Mather A.S., Needle C.L., 1998. The forest transition: A theoretical basis. Area, vol. 30, no. 2, pp. 117-124.

Munteanu C., Kuemmerle T., Boltižlar M., Butsic V., Gimmi U., Halada L., Kaim D., Király G., Konkoly-GyuRó E., KozAK J., LIESKOVSKÝ J., Mojses M., Müller D., Ostafin K., Ostapowicz K., Shandra O., Štych P., Walker S., Radeloff V.C. 2014. Forest and agricultural land change in the Carpathian region - a meta-analysis of long-term patterns and drivers of change. Land Use Policy, vol. 38, pp. 685-697.

NiedzIAŁKOWSKa E., 1981. Rzeźba terenu [in:] L. Starkel (ed.), Warunki naturalne zlewni Homerki i jej otoczenia, Dokumentacja Geograficzna, 3, Warszawa: Instytut Geografii i Przestrzennego Zagospodarowania PAN, pp.13-21.

Olah B., Boltižlar M. Gallay I., 2009. Transformation of the Slovak cultural landscape since the 18th century and its recent trends. Journal of Landscape Ecology, vol. 2., no. 2, pp. 41-55.

OSTAFIN K., 2009. Zmiany granicy rolno-leśnej w środkowej część Beskidu Średniego od połowy XIX wieku do 2005 roku. Kraków: Wydawnictwo Uniwersytetu Jagiellońskiego.

Rudel T., Coomes O., Moran E., Achard E., Angelsen A., Xu J., LAmBin E., 2005. Forest transitions: Towards a global understanding of land use change. Global Environmental Change, vol. 15, no. 1, pp. 23-31.
SOPO, 2006-2025. Anti-Landslide Protection System project, the National Geological Institute, http://geoportal.pgi.gov.pl/portal/page/portal/ SOPO [5 December 2016].

ŠEBO D., NováČEK J., 2014. Case study areas Pruské, Bohunice, Vršatské Podhradie and Krivoklát: Land cover changes 1949-2009. Land Use/ Cover Changes in Selected Regions in the World, vol. 9, pp. 57-62.

SojA M., 2008. Cykle rozwoju ludności Karpat polskich w XIX i XX wieku. Kraków: Instytut Geografii i Gospodarki Przestrzennej Uniwersytetu Jagiellońskiego.

SojA R., 2002. Hydrologiczne aspekty antropopresji w polskich Karpatach. Prace Geograficzne 186, Warszawa: Instytut Geografii i Przestrzennego Zagospodarowania PAN.

STASZKIEWICZ J., 1981. Zbiorowiska roślinne [in:] L. Starkel (ed.), Warunki naturalne zlewni Homerki i jej otoczenia, Dokumentacja Geograficzna, 3, Warszawa: Instytut Geografii i Przestrzennego Zagospodarowania PAN, pp. 43-50.

UlisZAK R., 2013. Wizja wsi małopolskiej - rok 2050 - spodziewane scenariusze zmian. Studia Obszarów Wiejskich, 31, pp. 67-82.

TroLL M., 1999. Lasy, ich przemiany i przestrzenne zróżnicowanie [in:] W. Widacki (ed.), Przemiany środowiska przyrodniczego zachodniej części Beskidów pod wpływem antropopresji, Kraków: Instytut Geografii Uniwersytetu Jagiellońskiego, pp. 15-32.

Whited T., 2000. Extinguishing disaster in alpine France: The fate of reforestation as technocratic debacle. GeoJournal, vol. 51, no. 3, pp. 263-270.

WoHl E., 2006. Human impacts to mountain streams. Geomorphology, vol. 79, no. 3, pp. 217-248.

WOLSKI J., 1998. Land use and cover changes in the evacuated rural areas (the case of Bieszczady Mts.). Miscellanea Geographica, 8, pp. 29-40.
(C) Anna Bucała-Hrabia

(C) Geographia Polonica

(C) Institute of Geography and Spatial Organization

Polish Academy of Sciences • Warsaw • 2017
Article first received • September 2016

Article accepted • December 2016 